REVIEW

\title{
Comparative histopathology of gonadal neoplasms in marine bivalve molluscs
}

\author{
Esther C. Peters ${ }^{1, *}$, Paul P. Yevich ${ }^{2}$, John C. Harshbarger ${ }^{1}$, Gerald E. Zaroogian ${ }^{2}$ \\ ${ }^{1}$ Registry of Tumors in Lower Animals, National Museum of Natural History, Smithsonian Institution, \\ Washington, DC 20560, USA \\ ${ }^{2}$ Environmental Research Laboratory, U.S. Environmental Protection Agency, 27 Tarzwell Drive, Narragansett, \\ Rhode Island 02882, USA
}

\begin{abstract}
Comparative histology of gonadal neoplasms in 14 marine bivalve species or hybrids from 5 countries described in the literature and/or archived in the Registry of Tumors in Lower Animals (RTLA), Washington, DC, USA, revealed 3 basic histotypes. Hundreds of cases were of germ cell origin with different stages of development. They consisted of undifferentiated germ cells that filled individual follicles (stage 1), were present throughout the gonadal area (stage 2), or had spread to outlying tissues (stage 3). Five cases were of stromal origin. The connective tissue comprising these tumors ranged from vesicular to myxoid to spindle-cell. As these tumors grew, they invaded and destroyed normal follicles. Three cases representing a third histotype appeared to be of both germ cell and stromal origin. Two of these 3 were among 15 Crassostrea virginica recently collected from the Pawcatuck River, Rhode Island, USA. In the most advanced case, basophilic hypertrophied neoplastic germ cells were rapidly proliferating along the walls of gonadal follicles and the ducts that extended into the mantle, while the central region of the tumor mass was densely fibrous. Some neoplastic cells in follicles adjacent to normal ova-bearing follicles were differentiating into spermatocytes. Tumor cells aggressively crossed the follicular basement membrane, invaded the vesicular connective tissue supporting the gill axis, and formed a cystic mass along the luminal wall of the branchial vein. The less advanced $C$. virginica case had a smaller, less aggressive tumor but its basic features were similar. The third case similar in composition, pattern, and behavior was in a C. gigas that had been collected during the 1960s from the Willapa Bay, Washington, USA, and had originally been interpreted as a fibroma. All 3 of these mixed gonadal-stromal neoplasms are presently diagnosed as gonadoblastomas.
\end{abstract}

KEY WORDS: Bivalve molluscs · Germinoma Gonadoblastoma · Histopathology

\section{INTRODUCTION}

Histoslides of 2 eastern oyster Crassostrea virginica specimens collected by one of the authors (P.P.Y.) and submitted to the Registry of Tumors in Lower Animals (RTLA; National Museum of Natural History, Smithsonian Institution, Washington, DC, USA) for diagnostic confirmation and accessioning contained a mass of abnormal tissue in the gonadal region. Microscopic examination of the histoslides revealed this mass to be an invasive neoplasm of poorly differentiated gonadal fol-

- Present address: Tetra Tech, Inc., 10306 Eaton Place, Suite 340, Fairfax, Virginia 22030, USA licles supported by abundant stroma. In one specimen some of the abnormal follicles contained either spermatid-like maturation products or young oocyte-like cells even though the specimen had an unequivocal female gonad in its normal areas. These features did not bring to mind any of the hundreds of gonadal tumors of germ cell origin or a small number of gonadal tumors of mesenchymal cell origin found in bivalve molluscs already in the RTLA's reference collection. Rather the differentiation of mixed cellular lineages suggested a more pluripotent cell of origin, a gonadoblast.

To test the hypothesis that these tumors were gonadoblastomas and not just a variation of the other 2 tumor types, all 178 cases of neoplasms arising in the 


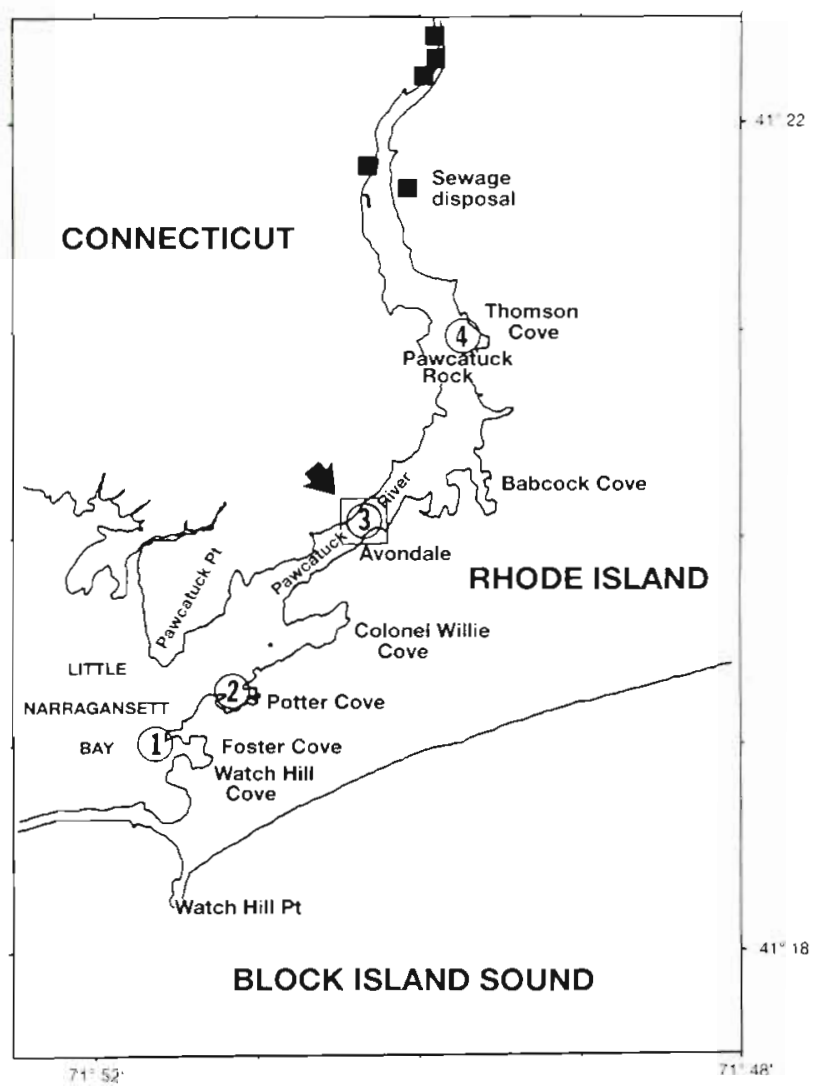

Fig. 1. Locations of the 4 sampling stations along the pollution gradient on the Pawcatuck River, Westerly, Rhode Island, USA. Tumors were found in oysters at $\operatorname{Stn} 3$

gonadal tissue of 14 species of marine bivalve molluscs from 3 continents in the RTLA's collection were reevaluated and compared. The results, presented here, include new geographic records and histologic information about gonadal tumor cases of both germ cell and mesenchymal cell origin not previously published. In addition, the new gonadoblastic tumor type is described and an earlier case of this type of tumor is identified.

\section{MATERIALS AND METHODS}

The gonadoblastic tumors were found among samples of Crassostrea virginica collected along a pollution gradient in the Pawcatuck River, between Connecticut and Rhode Island, USA (Fig. 1). Sources of pollution included a sewage treatment plant; individual sewage disposal systems; electronics, battery, and textile manufacturing firms; and marinas. Fifteen oysters, 4 to $6 \mathrm{~cm}$ in length, were sampled from each site on 17 March, 13 June, 7 September, and 1 December 1988. Specimens were fixed in Helly's, embedded in paraffin, sectioned at $6 \mu \mathrm{m}$, and stained with Gill's hema- toxylin (either Formulation no. 2 or no. 3) and eosin or eosin-phloxine for light microscopy (Zaroogian \& Yevich 1993). Additional slides were stained with either Masson's Trichrome (Luna 1968) or Cason's procedure for connective tissue (Cason 1950), a modified Van Gieson's to distinguish collagen from muscle fibers (Dodds \& Clark 1985), and with the PeriodicAcid-Schiff-McManus procedure, with and without diastase digestion, to demonstrate glycogen and various mucosubstances (Luna 1968, Sanders 1973). The oyster neoplasms were archived in the RTLA (accession numbers 4191 for the 13 June specimen and 5166 for the 7 September specimen).

The other bivalve gonadal neoplasms were collected from marine and estuarine habitats of 5 countries on 3 continents (Table 1) and were contributed to the RTLA between 1965 and the present. The RTLA was established in 1965 to diagnose and to build a reference collection of neoplasms and related disorders in invertebrate and poikilothermic vertebrate animals that would be freely available to scholars for comparative study. Materials included in each accession usually include one or more histoslides and may also include tissues, blocks, case histories, gross photographs, light and electron photomicrographs, and reprints. In the present study, special stains were applied to some of the extra tissues for more detailed evaluation.

\section{RESULTS}

\section{Pawcatuck River oyster neoplasms}

The new tumor type was found in 1 of 15 eastern oysters Crassostrea virginica collected from the Pawcatuck River site P3 in June 1988. The tumor measured almost $1.0 \times 0.5 \mathrm{~cm}$ after processing and appeared unusually basophilic at low power (Fig. 2). Another oyster collected at the same site during September 1988 had what appeared to be an early-stage lesion of the same type. All other oysters collected during the study exhibited development of gonadal follicles appropriate to the season. In June, 7 oysters were male and 8 were female, all in a mature state; in September, there were 5 male and 7 female post-spawning oysters from site P3, and 3 of neutral or unknown gender. No hermaphrodites were found at any of the sites on any of the sampling dates.

\section{Description of advanced lesion}

The tumor from the oyster collected in June was a mass of poorly formed gonadal follicles adjacent to the normal ovarian follicles that graded into a fibrous 
Table 1. Summary of gonadal neoplasms in marine bivalve molluscs in the Registry of Tumors in Lower Animals (RTLA), Smithsonian Institution. Relevant literature is cited in parentheses

\begin{tabular}{|c|c|c|c|c|c|}
\hline Species & Common name & RTLA no. & $\begin{array}{l}\text { Contributor } \\
\text { (publication) }\end{array}$ & Location & Diagnosis \\
\hline Arctica islandica & Ocean quahog & 4274 & P. P. Yevich & Rhode Island, USA & Germinoma \\
\hline Argopecten irradians & Bay scallop & 4045 & P. P. Yevich & Massachusetts, USA & Germinoma \\
\hline $\begin{array}{l}\text { Cardium (Cerasto- } \\
\text { derma) edule }\end{array}$ & Cockle & 4843,4844 & $\begin{array}{l}\text { E. Twomey } \\
\text { (Twomey \& Mulcahy } 1\end{array}$ & $\begin{array}{l}\text { Ireland } \\
\text { 1988j }\end{array}$ & $\begin{array}{l}\text { Germinoma, } 4843 \\
\text { also with hemo- } \\
\text { poietic sarcoma }\end{array}$ \\
\hline Crassostrea gigas & Pacific oyster & 37 & $\begin{array}{l}\text { G. B. Pauley } \\
\text { (Pauley \& Sayce 1968) }\end{array}$ & Washington, USA & $\begin{array}{l}\text { Fibroma or } \\
\text { myofibroma, } \\
\text { gonadal origin vs } \\
\text { gonadoblastoma }\end{array}$ \\
\hline \multirow[t]{4}{*}{ Crassostrea virginica } & \multirow[t]{4}{*}{ Eastern oyster } & 1748 & $\begin{array}{l}\text { S. V. Otto } \\
\text { (Harshbarger et al. } 197\end{array}$ & $\begin{array}{l}\text { Maryland, USA } \\
\text { 79) }\end{array}$ & Germinoma \\
\hline & & 5248 & $\begin{array}{l}\text { P. P. Yevich } \\
\text { (Gardner et al. 1987) }\end{array}$ & Rhode Island, USA & Germinoma \\
\hline & & 4191,5166 & $\begin{array}{l}\text { P. P. Yevich } \\
\text { (this paper) }\end{array}$ & Rhode Island, USA & Gonadoblastoma \\
\hline & & 4299 & P. P. Yevich & Rhode Island, USA & $\begin{array}{l}\text { Hyalinized fibroma, } \\
\text { follicles obliterated }\end{array}$ \\
\hline Macoma calcarea & Chalky macoma & 4782 & $\begin{array}{l}\text { R. E. Hillman } \\
\text { (Neff et al. 1987) }\end{array}$ & Canada & $\begin{array}{l}\text { Germinoma? and } \\
\text { hemopoietic } \\
\text { sarcoma }\end{array}$ \\
\hline \multirow[t]{3}{*}{$\begin{array}{l}\text { Mercenaria } \\
\text { mercenaria }\end{array}$} & \multirow[t]{3}{*}{ Northern quahog } & 1766 & S. V. Otto & Maryland, USA & $\begin{array}{l}\text { Germinoma (early } \\
\text { stage) }\end{array}$ \\
\hline & & $\begin{array}{l}1934 \\
2085-2090 \\
2137-2139\end{array}$ & H. Diamond & Rhode Island, USA & Germinomas \\
\hline & & $\begin{array}{l}3755 \\
4221-4223\end{array}$ & $\begin{array}{l}\text { D. M. Hesselman } \\
\text { (Hesselman et al. 1988) }\end{array}$ & Florida, USA & Germinomas \\
\hline \multirow[t]{2}{*}{$\begin{array}{l}\text { M. mercenarial } \\
\text { campechiensis }\end{array}$} & \multirow[t]{2}{*}{ Hybrid quahog } & 4940,4941 & $\begin{array}{l}\text { D. M. Hesselman } \\
\text { (Hesselman et al. } 1988\end{array}$ & Florida, USA & Germinoma \\
\hline & & 5556 & $\begin{array}{l}\text { A. G. Eversole, } \\
\text { P. B. Heffernan } \\
\text { (Eversole \& Heffernan }\end{array}$ & $\begin{array}{l}\text { South Carolina, USA } \\
\text { 1993) }\end{array}$ & Germinoma \\
\hline \multirow[t]{5}{*}{ Mya arenaria } & \multirow[t]{5}{*}{ Softshell } & $\begin{array}{l}1275-1317 \\
1319-1330 \\
1332-1334 \\
1340,1341 \\
1343-1345 \\
1347-1371\end{array}$ & $\begin{array}{l}\text { P. P. Yevich } \\
\text { (Yevich \& Barszcz } 1977\end{array}$ & Maine, USA & Germinomas \\
\hline & & $\begin{array}{l}1694-1703 \\
4043,4261 \\
4280-4282\end{array}$ & P. P. Yevich & Maine, USA & Germinomas \\
\hline & & $\begin{array}{l}1449 \\
1452-1458\end{array}$ & J. Hurst & Maine, USA & Germinomas \\
\hline & & $\begin{array}{l}1500,1501 \\
1503,1505 \\
1507-1510 \\
1513,1514\end{array}$ & E. Gilfillan & Maine, USA & Germinomas \\
\hline & & 2091 & $\begin{array}{l}\text { J. C. Harshbarger, } \\
\text { J. Hurst, R. Dow } \\
\text { (Harshbarger et al. } 197\end{array}$ & $\begin{array}{l}\text { Maine, USA } \\
\text { 79) }\end{array}$ & Germinomas \\
\hline
\end{tabular}


Table 1 (continued)

\begin{tabular}{|c|c|c|c|c|c|}
\hline Species & Common name & RTLA no. & $\begin{array}{l}\text { Contributor } \\
\text { (publication) }\end{array}$ & Location & Diagnosis \\
\hline \multirow[t]{3}{*}{ Mytilus edulis } & \multirow[t]{3}{*}{ Blue mussel } & 4300 & P. P. Yevich & Rhode Island, USA & $\begin{array}{l}\text { Ectopic ganglıa, } \\
\text { follicles }\end{array}$ \\
\hline & & 4322 & $\begin{array}{l}\text { P. P. Yevich } \\
\text { (Yevich et al. 1987) }\end{array}$ & Rhode Island, USA & $\begin{array}{l}\text { Focal polypoid } \\
\text { hyperplasia of } \\
\text { germinal epithelium }\end{array}$ \\
\hline & & 4788 & R. E. Hillman & New York, USA & Germinoma \\
\hline 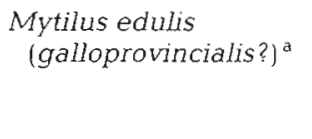 & Blue mussel & 1170 & P. H. Wolf & Tasmania & $\begin{array}{l}\text { Fibroma arising in } \\
\text { gonad or vesicular } \\
\text { connective tissue, } \\
\text { see also RTLA } 4299\end{array}$ \\
\hline 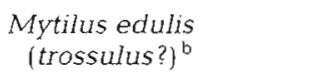 & Blue mussel & 4259 & P. P. Yevich & Washington, USA & $\begin{array}{l}\text { Chronic inflamma- } \\
\text { tion with fibrosis }\end{array}$ \\
\hline $\begin{array}{l}\text { Mytilus edulis } \\
\text { (trossulus/gallo- } \\
\text { provincialis hybrid?) }\end{array}$ & Blue mussel & 4295 & P. P. Yevich & California, USA & $\begin{array}{l}\text { Ectopic ganglia, } \\
\text { follicles, myxomas } \\
\text { in vesicular connec- } \\
\text { tive tissue }\end{array}$ \\
\hline $\begin{array}{l}\text { Mytilus sp. } \\
\text { (probably edulis) }\end{array}$ & $?$ & 1474 & $\begin{array}{l}\text { J. M. Ward, } \\
\text { A. Guarino, W. L. Doyl }\end{array}$ & Maine, USA & Fibrosarcoma \\
\hline Tiostrea chilensis ${ }^{c}$ & Bluff oyster & $\begin{array}{l}4848-4864 \\
5161-5164\end{array}$ & P. M. Hine & New Zealand & $\begin{array}{l}\text { Germinomas, } \\
\text { hemopoietic (?) } \\
\text { sarcoma }\end{array}$ \\
\hline \multicolumn{6}{|c|}{$\begin{array}{l}{ }^{b} \text { McDonald \& Koehn (1988). The nomenclature of the west coast Mytilus is still under debate } \\
{ }^{c} \text { Formerly T. lutaria. See Chanley \& Dinamani (1980) and Buroker et al. (1983) }\end{array}$} \\
\hline
\end{tabular}

center (Fig. 2). Tumorous follicle cells filled the follicles toward the periphery of the gonad, with a small focus of neoplastic follicles appearing near the gonoduct. The tumor mass also extended to the body wall, forming a distinct bulge near the gills. Swirling follicles and thickened stroma disrupted the connective tissue and muscle fibers underlying the branchial vein on other sections and formed a conical mass within the branchial vein. This mass had cystic areas, as did an area in the vesicular connective tissue of the gill axis.

Normal gonadal follicles were distributed distally from the digestive gland near the perimeter of the mantle tissue, with interconnecting branches of the follicles dispersed throughout the vesicular connective tissue (Leydig tissue). These normal follicles contained all stages of developing oocytes including scattered nests of germinal cells, minute follicular cells, and clusters of primary and secondary oocytes. The numbers of cells in these stages increased near the tumor mass. Large pedunculate oocytes predominated (Fig. 3), flattened into irregular shapes against the walls of the follicles as well as along the nonciliated wall of the genital canals. Vitellogenesis was nearing completion; a few mature ova had been released into the lumens of the follicles. Vesicular cells contained abundant glycogen. Major blood vessels in the mantle were cuffed by an inflammatory infiltration of phagocytes with fibrocytes. These fibrocytes were producing thick collagenous fibers that followed blood sinuses into the vesicular connective tissue. Brown cells, which contain translucent brown lysosomes used in detoxification (Zaroogian \& Yevich 1993), were abundant in the blood sinuses underlying the intestinal tract. The kidney exhibited a low-grade nephritis with destruction of renal tubules.

Figs. 2 to 7 Crassostrea virginica. Fig. 2. Low-magnification photomicrograph showing extent of tumor mass (T) in the gonad. Masson's Trichrome. MW: mantle wall; G: gills; NGD: normal gonadal follicles. Scale bar = $1 \mathrm{~mm}$. Fig. 3. Margin of the tumor; note normal mature follicles at left. Hematoxylin and eosin $(\mathrm{H} \& \mathrm{E})$. Scale bar $=50 \mu \mathrm{m}$. Fig. 4. Higher magnfication of proliferating germ cells at margin of tumor, showing differentiation into spermatic cells, and phagocytosıs (smaller arrows). H\&E. Scale bar $=25 \mu \mathrm{m}$. Fig. 5 . Mitotic figures in cells toward the center of the tumor mass (arrows). H\&E. Scale bar $=25 \mu \mathrm{m}$ Fig. 6 . Extensive fibrosis within tumor mass near mantle wall (MW); note tumor at blood vessel (V). Masson's Trichrome. Scale bar $=100 \mu$ m.

Fig. 7. Trapped glycogen-filled vesicular connective tissue cells (arrows). Periodic Acid Schiff procedure. Scale bar $=50 \mu \mathrm{m}$ 


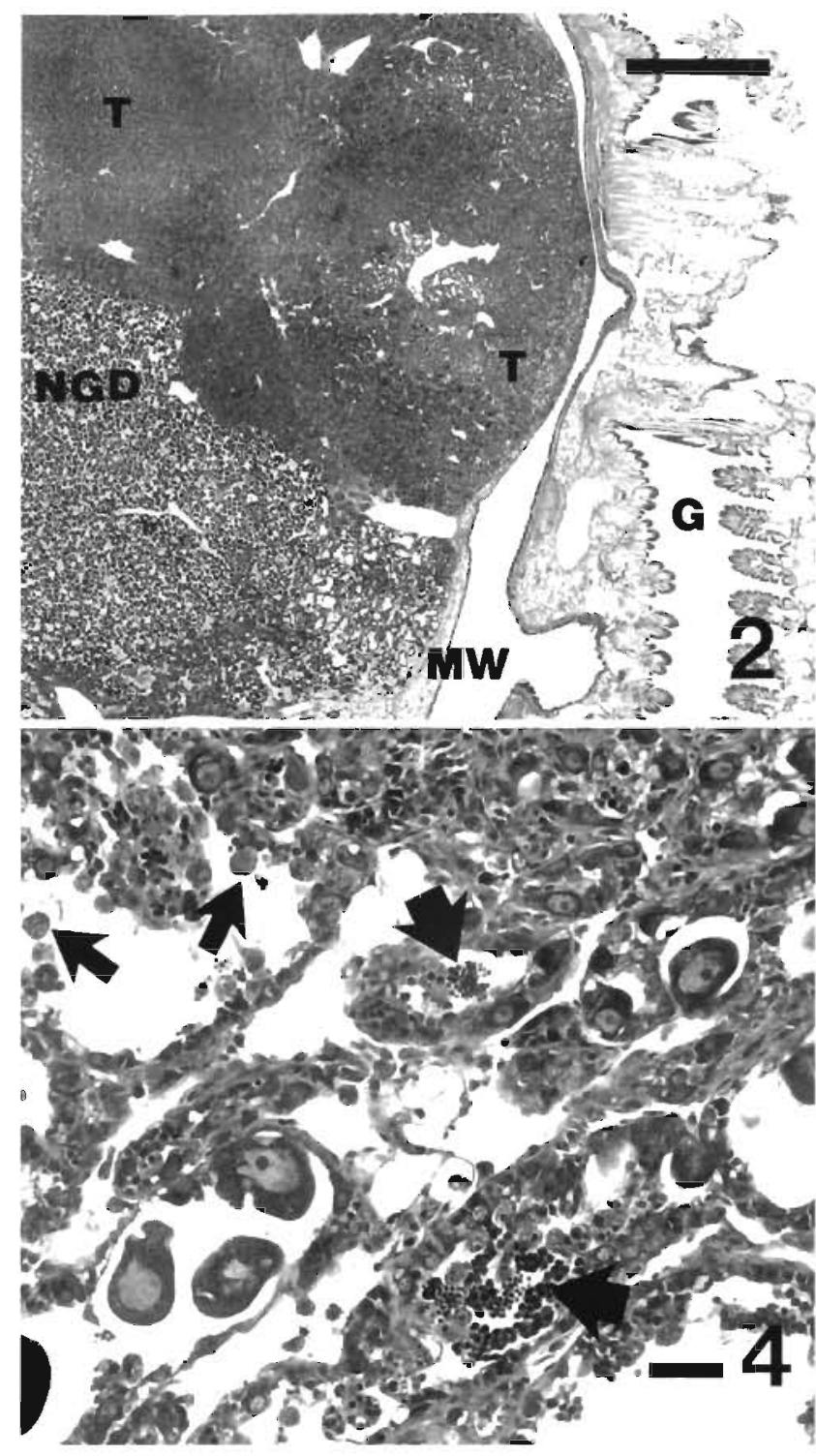

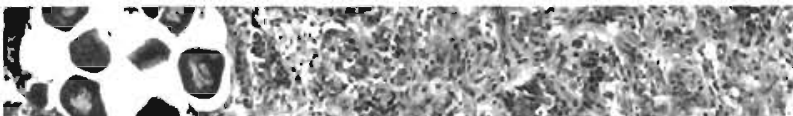

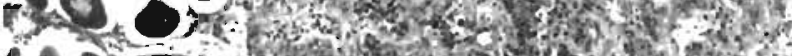

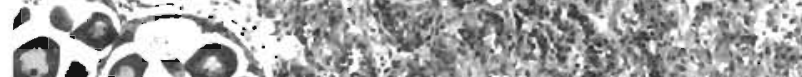

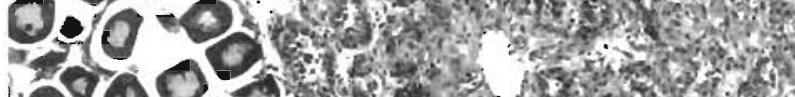

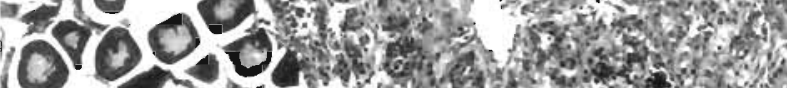

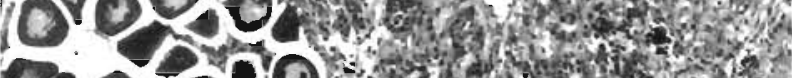

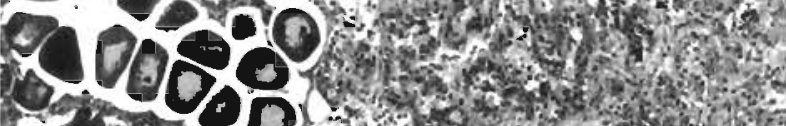

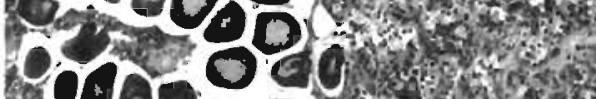

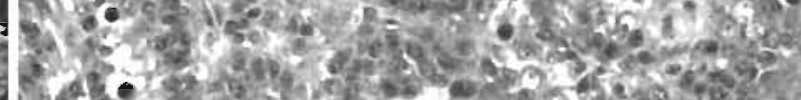

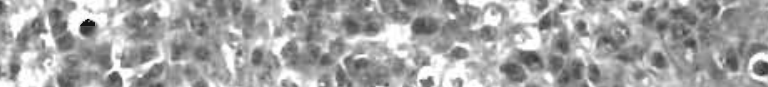

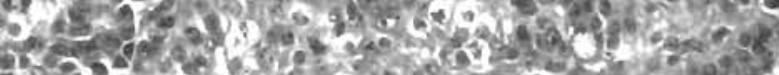

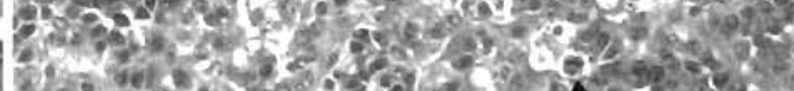

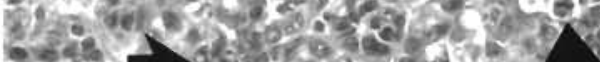
ogens

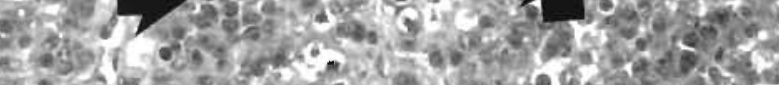

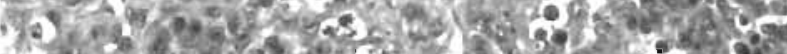

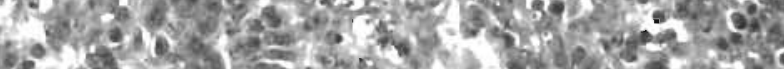

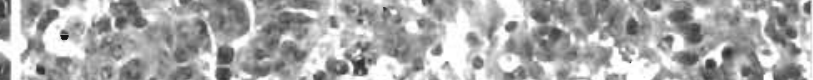

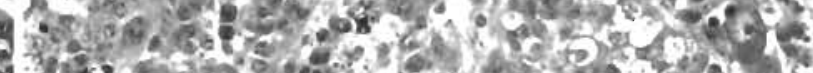

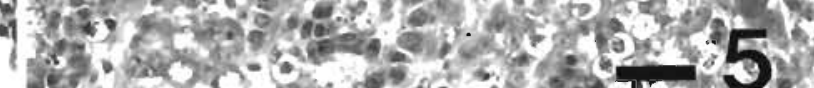

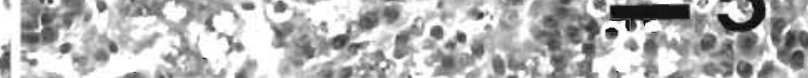

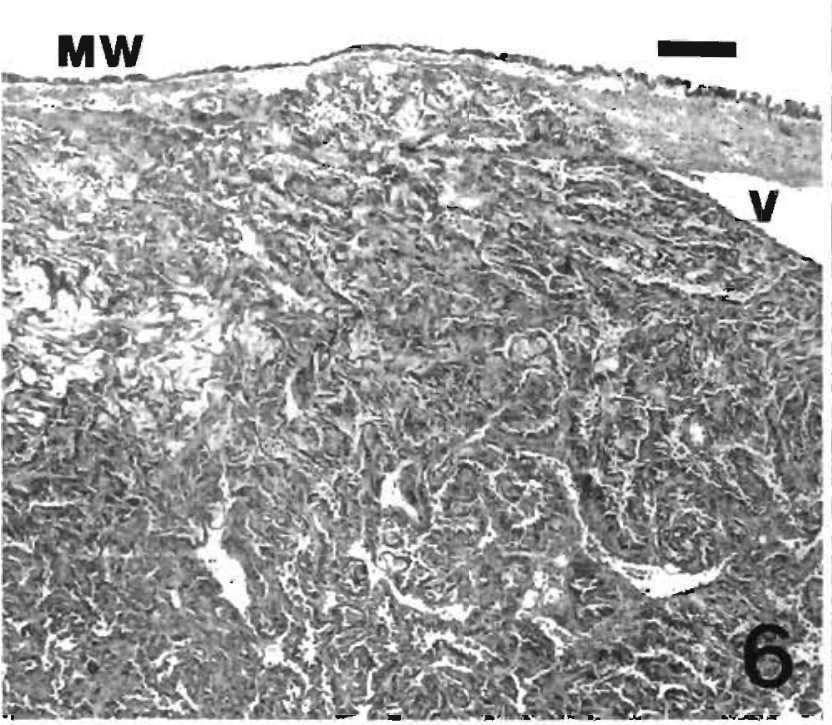

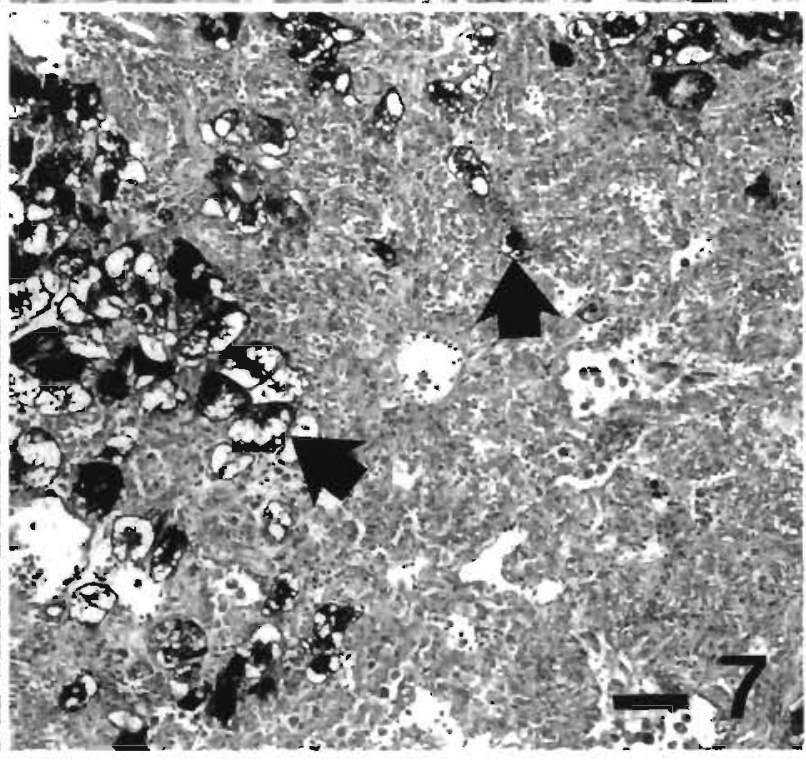


Adjacent to and interspersed with normal follicles at the periphery of the tumor (Figs. $3 \& 4$ ), poorly formed gonadal follicles were characterized by abundant pleomorphic basophilic cells approximately $4 \mu \mathrm{m}$ in diameter. The cells had scant cytoplasm, an enlarged nucleus with finely dispersed chromatin, and a prominent acidophilic nucleolus. Mitotic figures with distinct metaphase plates were apparent in round basophilic cells near the follicle wall (Fig. 5). Centripically, tumor follicles contained numerous cells with hypertrophied nuclei in meiotic prophase, primary and secondary spermatogonia, spermatids and spermatozoa. Some of these spermatic follicles were also present in the center of the tumor mass (Fig. 6). Female gonadal follicles trapped within the tumor mass were recognized by a few mature ova loose in lumens of the follicles, although occasional immature pedunculated ova were present. Most often, small basophilic oogonia were scattered among the neoplastic cclls at the tumor margin or occasionally deep within the tumor mass. Other stages of cell division were present, but not abundant. Phagocytes were numerous in the tumor areas, particularly in gonadal follicles containing spermatic cells which they were engulfing. Large brown cells, containing medium to large cytoplasmic globules, were scattered in both the vesicular connective tissue and the tumor mass.

The pattern of branching follicles could be discerned in much of the tumor, but there were large areas in which the follicular pattern was disrupted by interstitial fibrosis, resulting in a swirling pattern of collagenous fibers (Fig. 6). Fibrosis progressed from minor thickening of the basement membranes around each follicle to almost complete destruction of tumor follicles and adjacent vesicular connective tissue. Vesicular connective tissue was almost entirely excluded from the tumor area, except for a few cells trapped in the stromal mass. Though reduced in size they still contained glycogen (Fig. 7). Mitotic figures were also present in the stromal area. The region of the tumor with thickest stroma contained fewer basophilic cells, more free glycogen vesicles within follicles, and cells lining the follicle walls were more spindle-shaped. Tumorous follicle cells and associated stroma invaded walls of blood vessels within the tumor.

The cystic areas in the conical mass within the branchial vein resulted from the loss of basophilic cells that would normally fill the lumens of the altered follicles (Figs. 8 to 10). The cystic tissue was also found to extend around the vein and into the vesicular connective tissue of the gill axis (Fig. 9). Within the truncated mass seen in Fig. 10 were a number of hypertrophied cells containing acidophilic fine granules, resembling those red granular secretory cells normally found on the body wall. Inflammatory hemocytes were present in the lumens of the altered follicles.

\section{Early tumor development?}

The second oyster from the September collection with the earlicr stage of the same type of lesion displayed a small portion of the gonad (lost in subsequent serial sections) with abnormal proliferation of the germinal epithelium (Fig. 11). Approximately one-half of the normal follicles were filled with mature ova and the ova were being discharged into the gonoduct. The germinal epithelium of these normal follicles was not active. However, those follicles near the ciliated ducts contained a single layer of mitotically active basophilic cells on the wall, with some showing differentiation into primary oocytes with basophilic cytoplasm, prominent nucleus and nucleolus, and little yolk material. Follicles nearest the ciliated genital canals of the gonadal mass displayed hyperplastic germinal epithelium with interfollicular fibrosis. Basophilic cells approximately $4 \mu \mathrm{m}$ in diameter were piled several cells deep into the lumens of the follicles. Most cells had well-spread chromosomes, as in prophase, and appeared to be undergoing meiotic divisions reminiscent of spermatogenesis, although no spermatids or spermatozoa were seen. Necrotic cells were present in the hyperplastic epithelium but were rare in the follicle lumens.

Thickened collagenous fibers and spindle-shaped fibroblasts were replacing vesicular connective tissue

Figs. 8 to 12. Crassostrea virginica. Fig. 8. Low-magnification photomicrograph showing tumor cells infiltrating wall of branchial vein (arrow) to form a truncated mass. Note extent of tumor through the mantle. Masson's Trichrome. Scale bar $=1 \mathrm{~mm}$ Fig. 9. Invasion of cystic tumor mass into supporting vesicular connective tissue of gill axis (arrow) around the branchial vein ( $V$ ) Normal gill axis (NGA) is at upper left. H\&E Scale bar $=500 \mu \mathrm{m}$. Fig. 10. High magnification of truncated mass above, showing destruction of blood vessel wall and formation of follicular tissue. Masson's Trichrome. Scale bar $=100 \mu \mathrm{m}$. Fig. 11 . Hyperplastic germinal epithelium (arrow) in RTLA 5166. H\&E. Scale bar $=50 \mu \mathrm{m}$. Fig. 12. Germinoma of RTLA 1748. Note apparent ovum (O) and spermatocyte (S) differentiation and undifferentiated cells mixed with infiltrating hemocytes in vascular channels of vesicular connective tissue (large arrow). H\&E. Scale bar $=50 \mu \mathrm{m}$

Fig. 13. Arctica islandica. Focal proliferation of undifferentiated germ cells on follicle wall at arrows, characteristic of the germinoma of RTLA 4274. H\&E. Scale bar $=50 \mu \mathrm{m}$ 

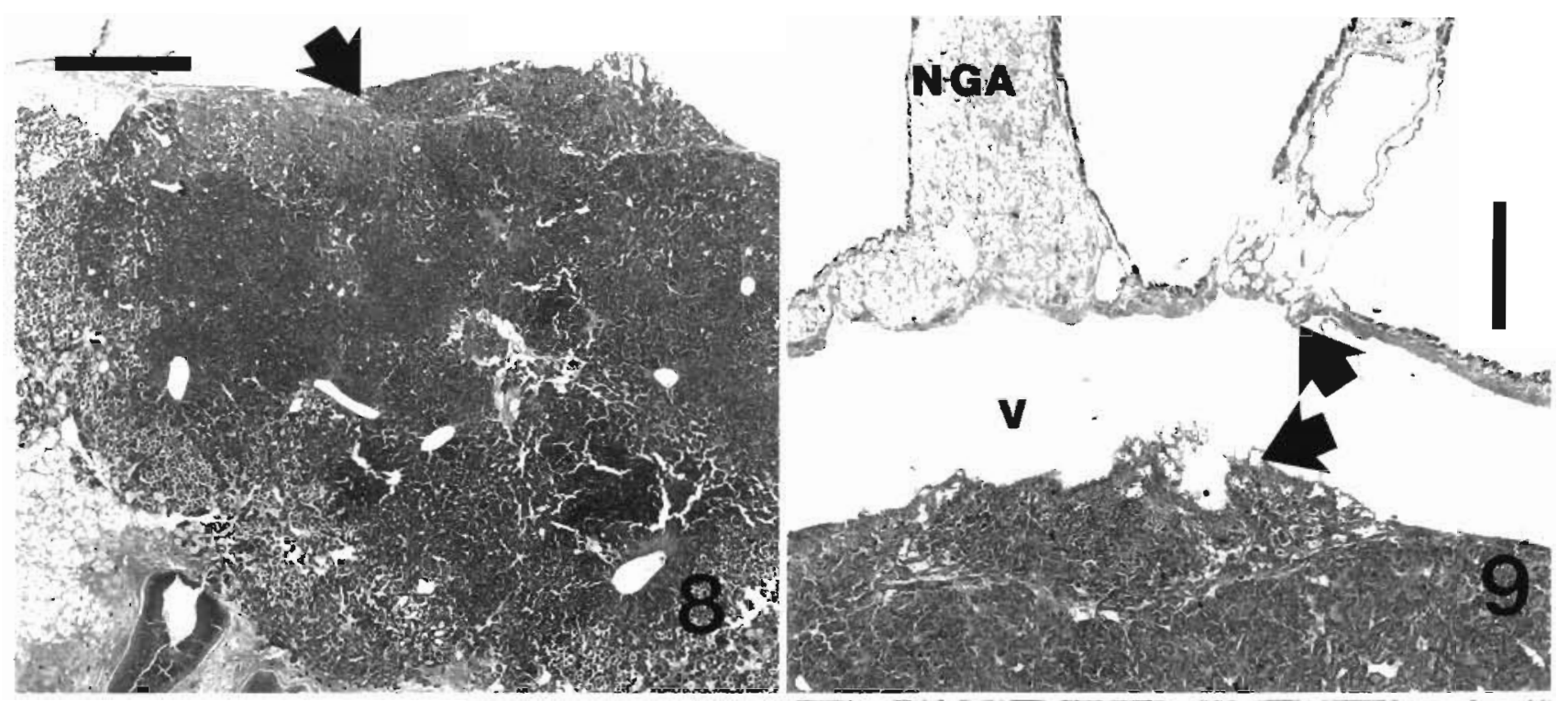
10.

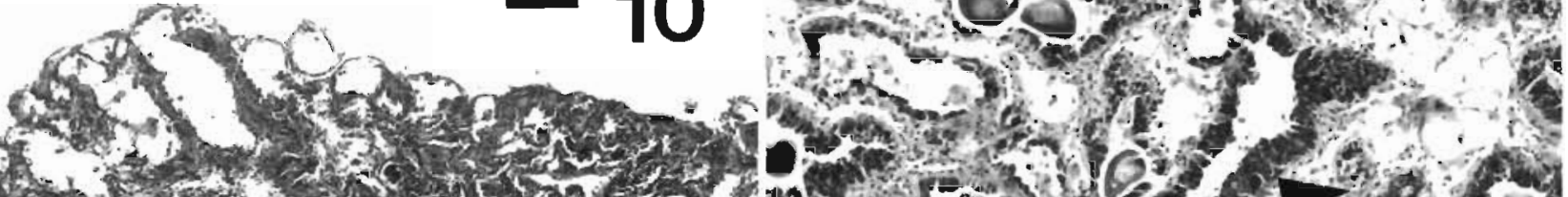
(1)
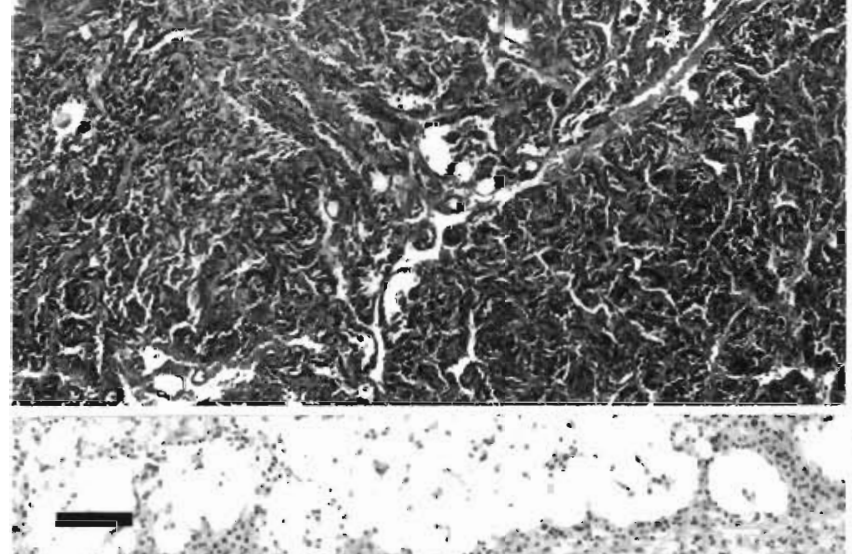

is $>10$

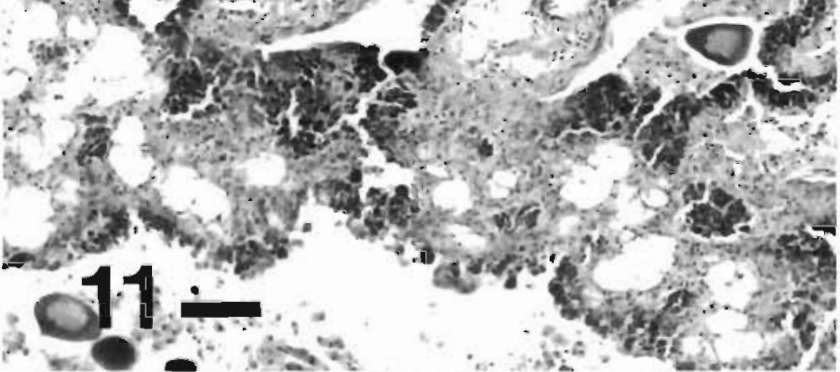

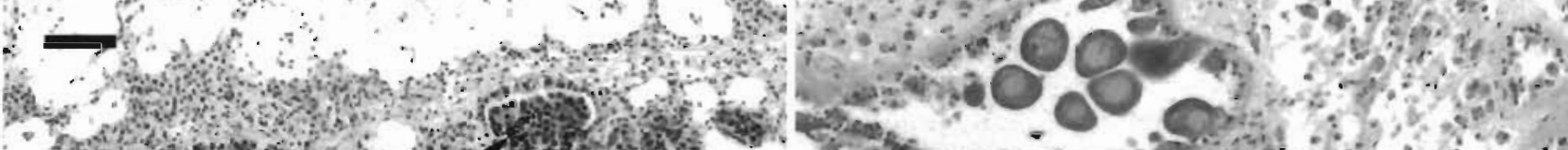
(0.6) 
between the follicles, especially in the area of hyperplastic germinal epithelium near the gonoduct. Granular hemocytes had infiltrated sinuses of the interfollicular vesicular connective tissue and were also numerous in connective tissue underlying the ciliated columnar epithelium of the digestive tract. Large phagocytes were present in lumens of affected follicles, but not in those still containing mature ova. Large brown cells containing small to medium globules were present throughout the vesicular connective tissue. In contrast to the more advanced lesion, this mass of abnormal tissue was not invading the vesicular connective tissue or blood vessels.

\section{RTLA bivalve gonadal neoplasms}

Germ cell tumors found in the RTLA material included rare cases as well as examples of germinomas known to be epizootic in 2 species of bivalves. Different stages of development were evident in the germinomas. The original diagnoses of several tumors, particularly those of mesenchymal origin, were changed based on our studies of these lesions. The prevalence and etiology of several RTLA cases are still being investigated by their contributors, and these will not be described here.

\section{Anecdotal tumors of germ cell origin in the eastern} oyster

Farley (1976) reported the first germ cell neoplasm in Crassostrea virginica, found in 1 out of 50 oysters collected in the Mispillon River, Delaware Bay, USA. The tumorous gonadal follicles of this oyster contained round anaplastic cells resembling undifferentiated gametocytes, apparently originating from the germinal epithelium. These cells filled the follicles and oviduct, with diffuse invasion through the connective tissue spaces, walls of blood vessels, and the gastrointestinal tract epithelia. He diagnosed this neoplasm as either a dysgerminoma or a seminoma, since the sex of the oyster could not be determined.

Two similar cases, found by S. V. Otto, were reported by Harshbarger et al. (1979) from a study of 20000 oysters collected from 23 sites in the Chesapeake Bay, USA. One animal each from off St. Mary's and off Punch Island possessed follicles packed with mitotically active undifferentiated germ cells. Tumor cells in the latter case (RTLA 1748) had large basophilic nuclei containing a prominent nucleolus and scant cytoplasm (Fig. 12). They were disseminated in the connective tissue and blood sinuses, and the epithelium of the tubules in the digestive diverticula. Many follicular walls had been destroyed. The only indications of possible differentiation were the appearance of small clusters of cells with condensed nuclei resembling spermatogonia trapped in many of the follicles and 1 follicle that contained 3 early oocytes attached to its wall. Hemocyte infiltration was extensive throughout the tissues and was most notable near the affected follicles, but fibrosis appeared minimal. The reason for this inflammatory response was undetermined. Polydora sp. parasites were embedded in the shells.

Another case resembling this type of germinoma was found in a specimen of Crassostrea virginica (RTLA 5248) from a $31 \mathrm{~d}$ laboratory exposure to Black Rock Harbor dredged sediments (Gardner et al. 1987). Undifferentiated cells similarly formed a thick layer inside the follicular walls, but centrally the lumens were packed with phagocytes and remnants of spermatozoa. Extrafollicularly, inflammatory cells were limited to one focus near the gonoducts where the interfollicular vesicular connective tissue was almost obscured. Only a few of the germ cells lining the follicle walls showed any suggestion of differentiation into basophilic early oogonia.

Anecdotal tumors of germ cell origin in other marine bivalves

A germinoma in an ocean quahog Arctica islandica (RTLA 4274) resembled the Crassostrea virginica lesions. It consisted of small basophilic cells containing slightly hypertrophied nuclei with marginated chromatin and 1 to 2 prominent red-staining nucleoli. These abnormal cells formed small masses several cells deep extending into lumens of follicles, especially near the junction with the ciliated ducts (Fig. 13). Normal follicles, in contrast, contained either mature ova, ova in resorption, or regenerating germinal epithelium. A few mitotic figures were present.

Similar-appearing abnormal cells formed compact masses that partially or completely filled about onequarter of the spermatogenic follicles in a hermaphrodite bay scallop Argopecten irradians (RTLA 4045), but most of the follicles contained normal maturation stages of spermatogonia to spermatozoa (Fig. 14). Mitotic figures and multiple nucleoli were more frequent in this lesion than in the Arctica islandica.

A possible germinal neoplasm was also found in a specimen of Macoma calcarea (RTLA 4782) from Baffin Island, Canada. This animal was originally submitted to the RTLA because it exhibited possible hemopoietic neoplasia (Neff et al. 1987) but delayed fixation made interpretation difficult. Most gonadal follicles appeared normal. They were filled with a lacy network of cells supporting an intensely basophilic germinal epithelium near the basement membrane, with a few 
germ cells differentiating through several stages into oogonia. However, one small area near the edge of the section contained several follicles filled with round undifferentiated basophilic cells with hypertrophied nuclei, 1 or 2 prominent acidophilic nucleoli, and scant cytoplasm. A few cells were dividing. The failure of the dividing cells to differentiate favored an interpretation of germ cell neoplasm over normal gametogenesis.

A blue mussel Mytilus edulis (RTLA 4788) from Throgs Neck, Long Island Sound, New York, USA, exhibited mitotically active basophilic pleomorphic cells filling all of the gonadal follicles sectioned. The cells arose from the germinal epithelium and appeared to extend in loosely-defined palisades toward the ciliated epithelium on the opposite wall. Nuclei had finely dispersed chromatin and usually 1 , but frequently 2 , nucleoli. There was no evidence of maturation of the germ cells. Immature cells filled the lumens of the follicles but did not appear to have crossed the basement membrane into surrounding tissues. The rest of the tissues appeared in good condition, without inflammation or fibrosis.

A Mytilus edulis exposed to contaminated dredged sediments from Black Rock Harbor, Connecticut, USA, in a laboratory experiment, exhibited masses of undifferentiated germ cells arising from the wall of the follicle and extending into the lumen, forming a polypoid germinal epithelium. These polypal masses were scattered throughout the gonad, and the follicles were filled with mature ova (RTLA 4322; Yevich et al. 1987). Cosson-Mannevy et al. (1984) reported a single specimen with a gonadal neoplasm in $M$. edulis from British Columbia, Canada.

Two examples of abnormal gametogenesis in which the follicles were partially or completely filled with mitotically-active undifferentiated cells from the germinal epithelium have been found in the cockle Cardium (Cerastoderma) edule from Ireland (RTLA 4843, 4844).

\section{Epizootic tumors of germ cell origin}

Among the above anecdotal cases, abnormal cells were generally confined to lumens of follicles. However, the capacity for invasion was clearly demonstrated in some individuals of Crassostrea virginica (RTLA 1478) where basophilic cells with hypertrophied nuclei were scattered in connective tissue. These cases also displayed moderate inflammatory responses. Likewise epizootic germinomas found in quahogs (Mercenaria spp. and their hybrids), softshells (Mya arenaria), and the oyster Tiostrea chilensis mostly consisted of focal tumors within follicles, but cases demonstrating moderate to highly aggressive invasion were also included in the RTLA collection.
Primary germ cell tumors were first reported in molluscs by Yevich \& Barry (1969). One of the 3 cases they described in female Mercenaria mercenaria (out of 1300 individuals collected) had early invasion to the supporting connective tissue in the kidney area. Subsequently 12 more cases out of 31.6 females and 2 cases in 223 males were collected from the same site near Rose Island in Narragansett Bay (Barry \& Yevich 1972). One dysgerminoma had invaded the red gland and genital pores, with metastatic tumor cells also attached to the heart muscle and a mass of tumor cells in the pericardial cavity.

Hesselman et al. (1988) found seasonally dependent incidences of this lesion in up to $23 \%$ of male and female Mercenaria spp. in the Indian River, Florida, USA. One female specimen (RTLA 3755) showed an extensive proliferation of atypically fusiform neoplastic germ cells that were aggressively invading and destroying vesicular connective tissue, adjacent muscles, and the connective tissue underlying the stomach and in the typhlosole. Neoplastic cells also penetrated and adhered to the endothelium of hemolymph vessels and appeared within lumens of vessels and vascular sinuses. Three other invasive cases are now known from this location. $M$. mercenaria, $M$. campechiensis, and their hybrids cultured in estuaries near Charleston, South Carolina, USA, also showed high prevalences and incidences of germinomas, and some invasive cases, in collections made in 1988 and 1992 (Eversole \& Heffernan 1993). The germinomas were most frequently found in the hybrids (RTLA 5556) and in the warmer months with prevalences from approximately 45 to $80 \%$ in 1988 and 95 to $100 \%$ in 1992 (A. G. Eversole, Clemson University, Clemson, South Carolina, and P. B. Heffernan, University of Georgia, Savannah, Georgia, unpubl.). Other observations suggest that mutations occurring in genes of hybrid Mercenaria spp. may increase their susceptibility to gonadal neoplasia (Bert et al. 1993, Van Beneden et al. 1993).

Germinomas in male and female quahogs (Mercenaria spp. and their hybrids) from Rhode Island, Florida, and South Carolina were generally characterized by replacement of normal germinal epithelium with large polyhedral tumor cells containing vesicular nuclei and a clear pink cytoplasm. Many tumor cells had marginated chromatin with bodies suggestive of herpes virus-like Cowdry Type A intranuclear inclusions (Farley 1978) and prominent acidophilic nucleoli. However, attempts to visualize virus particles by electron microscopy have all been negative (Hesselman et al. 1988, C. A. Farley \& S. C. Chang pers. comm.).

The Registry has also archived more than $100 \mathrm{ger}-$ minomas from both sexes of the softshell Mya arenaria, collected from Searsport, Maine, USA. These 
cases, which range from non-invasive to metastatic, have been described and discussed by Barry \& Yevich (1975), Yevich \& Barszcz $(1976,1977)$ [who reported incidences of $124 / 2053(6 \%)$ and $9 / 72(12.5 \%)]$. Brown et al. (1977) [7/192 (3.6\%)], and Harshbarger et al. (1979) (up to $22 \%$ of the sample afflicted). The walls of affected follicles were sometimes abnormally thickened compared to those of adjacent normal follicles (Fig. 15), but there was no general interfollicular fibrosis. Mitotically active, undifferentiated, small pleomorphic basophilic cells filled follicles; after follicles were filled tumor cells invaded interfollicular connective tissue, body wall, epibranchial chamber, and genital and urinary pores; and finally circulated to distant locations. Circulating neoplastic cells formed small foci in efferent blood vessels of the gill, pericardial wall, heart, kidney, red gland, and ganglion. Normal tissues were destroyed by the advancing tumor. Some cells were either multinucleated or contained minute intranuclear inclusions postulated to contain virus (Harshbarger et al. 1979), but this was not confirmed by electron microscopy (S. C. Chang pers. comm.). None of these $M$. arenaria germinoma cases showed disseminated abnormal cells like those found in the hemopoietic sarcoma known in this species (Peters 1988). Neither did any of these softshell germinomas co-occur in clams with hemopoietic neoplasms nor have they been found in clams from the same localities as those with hemopoietic neoplasms as stated by Elston et al. (1992).

Another example of an epizootic germ cell neoplasm was recently found in male oysters Tiostrea chilensis from several sites off New Zealand (RTLA 4848-4864, 5161-5164).

\section{Gonadal neoplasms of stromal origin in marine} bivalves

A Crassostrea virginica (RTLA 4299) from Rhode Island had 2 fibrous masses of tissue. The larger mass arose in interfollicular vesicular connective tissue of the reproductive tract (Fig. 16). It had obliterated gonadal follicles, although a few spermatocytes were trapped in the mass. Ciliated canals directly adjacent to this tissue mass (toward the edge of the mantle) were normal, but lacked the developing spermatocytes filling surrounding follicles and ducts. The mass was composed of a fine network of fibers and lightly acidophilic ground substance. Nuclei were small, ovoid to fusiform or stellate, and randomly scattered. Darker acidophilic fibrils accumulated on the periphery of the mass, perhaps remnants of collagens from between the vesicular cells that had been replaced by the tumor The interior of the tumor was irregular and displayed numerous open channels or cysts containing granular hemocytes infiltrating this area of the tumor from the blood vessels. A moderate inflammatory response was present throughout the connective tissue of the oyster. A second plane section from this oyster revealed a large, bulbous mass of fibrous tissue outlined in cuboidal to columnar secretory epithelial cells. The epithelium resembled abnormal mesothelium and extended into the pericardial cavity. It was composed of thicker, more strongly acidophilic, criss-crossed fibers and small spindle-shaped fibrocytes that were extensively infiltrated with inflammatory cells. The proximal portion of the mass contained numerous atrophied gonadal follicles with abnormal spermatogonia in apparent arrested development. These lesions were interpreted as hyalinized fibromas.

A similar lesion occurred in RTLA 1170 , a specimen of Mytilus edulis (= galloprovincialis?) from Tasmania. A large, spherical mass of tissue dominated one area of the reproductive tract on one histoslide. The tissue was composed of clumps of normal-appearing vesicular connective tissue interspersed with thick bands of acidophilic fibrous tissue and pleomorphic cells with fusiform or stellate nuclei and little myxoid-type tissue. Much of the tumor was infiltrated with hemocytes, often in dilated vascular channels.

A rare hermaphroditic Mytilus sp. from Maine (RTLA 1474), exhibited dense fibrous tumor masses in both the male and female portions of the gonadal tissue (Fig. 17). Follicles containing either ova or spermatozoa were trapped within the advancing tumor tissue and were being obliterated along with trapped vesicular connective tissue. Tumor cells were fusiform in a swirling pattern. They had a finely granular or fibrous acidophilic cytoplasm with elongate nuclei that were

Figs. 14 to 19. Various bivalve species. Fig. 14. Germinoma of Argopecten irradians, RTLA 4045. Undifferentiated germ cells with prominent nucleoli are filling in follicles containing spermatozoa (arrow). H\&E. Scale bar $=50 \mu m$. Fig. 15. Germinoma of Mya arenaria, RTLA 1316, showing slight thickening of basement membrane around follicles at arrows. A single normal follicle (NGD) with developing ova is at bottom center. H\&E. Scale bar $=50 \mu \mathrm{m}$. Fig. 16. Hyalinized fibroma (arrow) in Crassostrea virginica, RTLA 4299. H\&E. Scale bar $=50 \mu \mathrm{m}$. Fig. 17. Fibrosarcoma (arrow) in male gonad of Mytilus sp., RTLA 1474. H\&E. Scale bar $=$ $250 \mu \mathrm{m}$. Fig. 18. Gonadal tumor (T) from Crassostrea gigas, RTLA 37 (Pauley \& Sayce 1968). Note invasion of vesicular connective tissue towards digestive gland (arrow), normal follicles (NGD) are at upper left. H\&E. Scale bar = $1 \mathrm{~mm}$. Fig. 19. High magnification of gonadal tumor in Fig. 18. Trapped normal follicles are at arrows. Note apparent fibrosis and possibie differentiation of cells into spermatocytes widely disseminated in the tissue Compare with Figs. $3 \&$ 7. H\&E. Scale bar $=50 \mu \mathrm{m}$ 


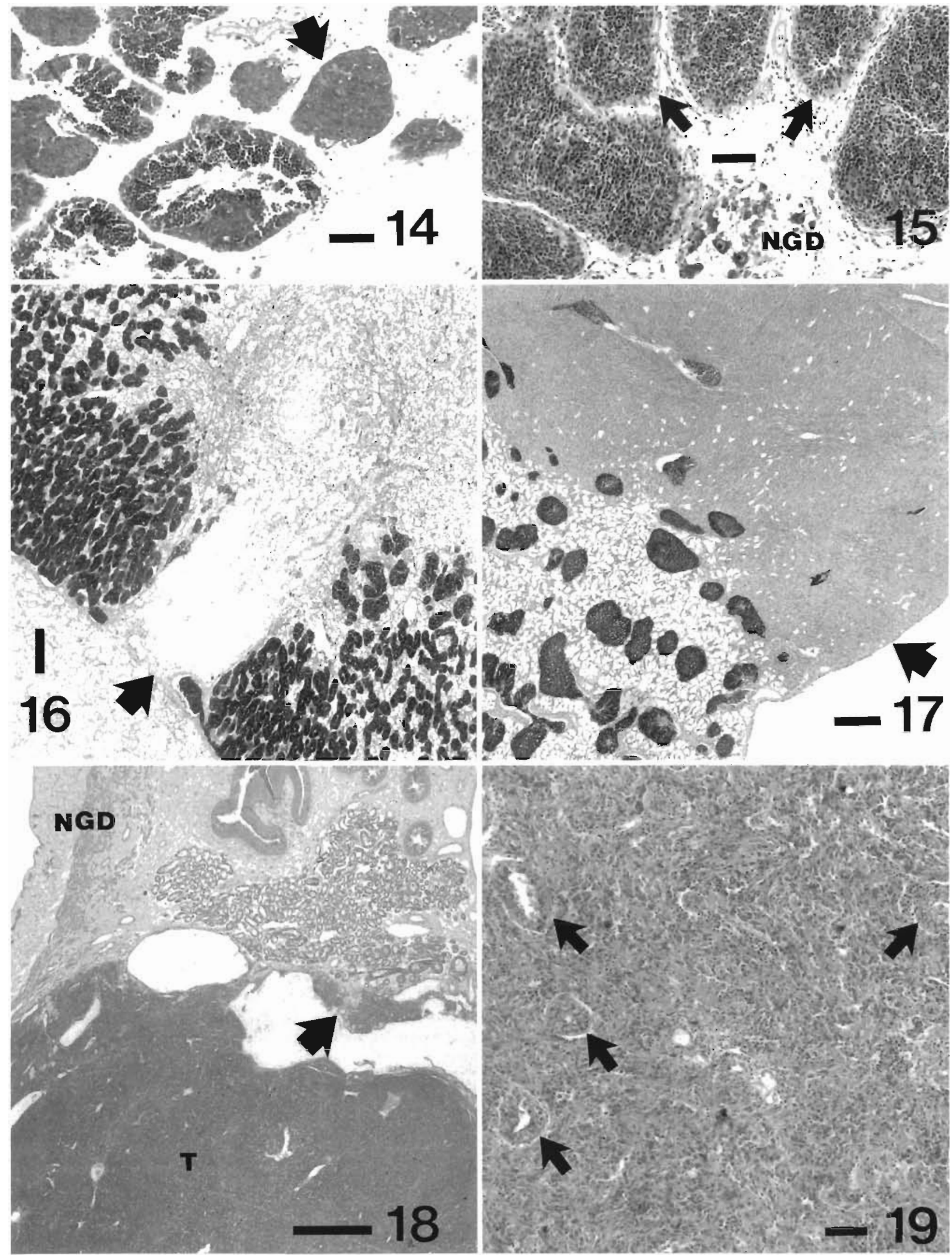


arranged in palisades. Mitotic figures could not be discerned and inflammation was not apparent. These features were consistent with a diagnosis of fibrosarcoma that arose in the gonadal stroma.

Pauley \& Sayce (1968) reported a fibroma in a Pacific oyster Crassostrea gigas from Washington, USA (RTLA 37). A large mass of tissue consisted of either pleomorphic cells with large rounded nuclei and finely dispersed chromatin in a well-developed stroma, sometimes arranged in a follicular pattern (Fig. 18). In other foci, however, there were intensely basophilic small nuclei in a stroma in which the acidophilic fibers were more pronounced. Small sections of follicles containing developing germinal epithelium were occasionally present in the tumor, resembling the germinal epithelium of follicles around the periphery of the mass (Fig. 19). These cells appeared to be differentiating into oocytes. A few mitotic figures were present. There was heavy infiltration of hemocytes into the tumor, but no increased blood vessel formation. Small foci of hyperchromatic nuclei and, occasionally, vesicular connective tissue, were also scattered in the tumor.

\section{Nonneoplastic gonadal lesions}

The diagnosis of tumors and other cellular proliferative disorders often requires careful study to properly interpret unusual conditions. The following cases are representative of two types of such problematic lesions found in gonadal tissues of marine bivalves archived in the RTLA.

A mussel Mytilus edulis (RTLA 4259) exhibited an unusual cellular proliferation throughout the tissues which suggested a neoplastic disease. Most of the gonadal follicles contained sperm in all stages of normal maturation, and several follicles were packed with spermatozoa. However, about two-thirds of the visible follicles and ducts were invaded by masses of large polygonal cells with a finely fibrillar to granular eosinophilic cytoplasm and a large nucleus. The nuclei of these cells were pleomorphic, with finely dispersed chromatin and a prominent excentric eosinophilic nucleolus. In some follicles the cells were fusiform and arranged in swirling patterns. Sometimes these cells were mixed with granular hemocytes or phagocytes and with necrotic cells and debris, particularly in lumens of gonadal ducts. Normal maturation of spermatogonia seemed to be arrested in follicles where the lumens were filled with the abnormal cells. It was difficult to distinguish mitoses of these abnormal cells from normal meioses of the spermatogonia that were trapped in the masses. Abnormal cells occurred in interfollicular vesicular connective tissue, and the connective tissue of the digestive gland, byssus gland, and foot; they were also found near the auricle and in vascular channels of the gill filaments, with a fibrous proliferative response in tips of some filaments and disruption of normal ciliated columnar epithelium. Mitotic figures occurred in scattered cells throughout the tissues. Although these cells were similar to the gonadal stem cells located on the follicle walls, they more closely resembled fibroblasts. Their distribution suggested that the abnormal cells arose in connective tissue and invaded gonadal follicles as the basement membrane was breached (with some suggestion of this visible in the sections). Although the cellular proliferation and behavior suggested a neoplastic disease, this lesion was interpreted to be an extensive chronic inflammatory response with fibrosis.

The RTLA also has 2 cases we have interpreted as ectopic ganglia in the follicles of specimens of Mytilus edulis (RTLA 4300) and $M$. trossulus/galloprovincialis hybrid (RTLA 4295). Small masses of neurons and nerve fibers (neuropil) appeared to arise from the germinal epithelium and fill the follicles. Normal germ cell development was absent. Differential diagnoses could also be metaplasia, abnormal transformation of differentiated tissue into another kind of differentiated tissue, or heteroplasia, the development (not replacement) of cytologic elements that are not normally found at a particular site (Stedman's Medical Dictionary 1982). In studies of thousands of serial sections of young freshwater clams Corbicula fluminea, Kraemer (1986) observed the development of follicular ganglia that appear to be involved in sperm maturation and self-fertilization during reproduction in this species. The development of follicular ganglia has not been reported in marine bivalves. Additional studies are needed to determine whether the ganglia found in the follicles of Mytilus spp. represent a normal stage in the life history or an abnormal response to an exogenous or endogenous factor.

\section{DISCUSSION}

Tumors of the human gonad arise in a variety of cell types and manifest pathological changes not only anatomically but also functionally (Scully 1979). Reproductive tumors in bivalves may also have diverse origins. However, prior to this review, with the exception of the one stromal-like tumor reported by Pauley \& Sayce (1968), all published reports on gonadal neoplasms in bivalves were limited to undifferentiated germ cell neoplasms.

The appearance and behavior of the germ cell tumors covered in this paper varied both between and within bivalve species. Some of this variability may be due to the particular structure of the gonadal follicles 
while other variability may be due to basic genetic differences in gonadal stem cells (GSC). The 2 main cell lineages of the gonadal ducts and follicles are the supporting cells, also known as Sertoli cells in male follicles and follicle cells in female follicles, and the gametocytes. Both of these cell types are believed to be derived from this GSC type, which persists in the adult, although there has been disagreement over this interpretation of gonad development (Nieuwkoop \& Satasurya 1981, de Jong-Brink et al. 1983). Furthermore, little is known of endocrine factors regulating the reproductive cycle in molluscs (de Jong-Brink et al. 1983, Maxwell 1983).

\section{Evaluation of gonadal neoplasms in Crassostrea spp.}

The 6 cases of Crassostrea tumors arising in gonadal tissue represent a range of cellular morphologic and behavioral variation. Our understanding of the nature of these neoplasms, however, will require further study of normal gonadogenesis, as well as pathologic conditions.

\section{Sexual differentiation in the oyster}

Normal gonadogenesis for the protandric Crassostrea virginica was described by Galstoff (1964) Primordial gonads of diffusely branching tubules begin to develop at from 6 to $10 \mathrm{wk}$ of age. At this stage, the germinal epithelium is a layer of undifferentiated cells which on one side of the tubule gives rise to germ cells and supporting cells. The ciliated epithelium which lines the other side of the tubule differentiates into genital canals at the surface of the gonad. By 12 to $16 \mathrm{wk}$ the primary gonad is bisexual, containing germinal cells of both sexes. As the oyster matures, the relative abundance of different sex phases of young individuals varies with age and environment. During winter of this first year, the growth of ovocytes is inhibited and the number of spermatogenic cells increases. The spermaries still retain a number of ovocytes on follicular walls. These ovocytes are capable of being fertilized. At the first breeding season, males predominate, but a small percentage of oysters will develop into females as the growth of ovocytes inhibits spermatogenesis.

Galstoff (1964) found that during the second breeding season the sex ratio approached equality, but this varied greatly with location of the population. He also noted that 'After spawning, the gonad of $C$. virginica retains its bisexual potencies and its sex may alternate in either direction' (Galstoff 1964, p. 316). His studies of oysters over a 5 yr period showed that out of 68 sur- vivors, 18 had changed sex once, 10 twice, 2 had alternated 3 times, and 1 oyster had changed from male to male with 4 alternations. Although sexes of the adults are usually separate, functional hermaphrodites, in which the eggs and sperm are found together and may be self-fertilized, can occur. However, hermaphrodites usually make up less than $2 \%$ of the population up to 4 yr of age and occur only rarely thereafter (only 2 out of several thousand sexually ripe oysters from 5 to $7 \mathrm{yr}$ old).

The ability of Crassostrea virginica to alternate the sexual differentiation of germ cells provides clues to the appearance of the unusual lesions seen in the 2 specimens from the Pawcatuck River. Their medium to large size suggested that they were past their second breeding season. Although many follicles in these specimens contained differentiating ovocytes and spermatocytes, this condition was not the same as the bisexual gonad described in Galstoff (1964). The tumors apparently arose in a pluripotent cell and perhaps some factors affected hormonal regulation of gametogenesis, leading to differentiation of spermatocytes within the neoplasm in the female oyster. Conversely, the $C$. virginica cases from the Chesapeake Bay (RTLA 1478) and Rhode Island (RTLA 5248) contained recognizable male germ cells, with very rare differentiation of female germ cells. Until more specimens of $C$. virginica exhibiting this lesion are found for study, however, it is difficult to evaluate the significance of this condition.

\section{Tumor progression}

The large number of softshell and quahog germinomas in this study permitted the recognition of 3 stages of tumor progression. In stage 1, mitotically active undifferentiated pleomorphic cells fill the lumens of 1 to many follicles. The follicular basement membrane is breached in stage 2 , with neoplastic cells invading adjacent tissues. In stage 3 , the neoplastic cells appear in the vascular sinuses and blood vessels at sites removed from the primary tumor, such as the gills, forming small clusters.

Sparks (1985) cautioned against applying the designation of metastasis in small animals with open circulatory systems because apparent satellite tumors may still be connected to the primary tumor. However, our examinations of numerous serial sections have failed to disclose any connection of the satellite tumors found in the gills of Mya arenaria with the primary tumor in the gonad, demonstrating that these germinomas are capable of metastasis. This is supported by recent studies of the invasive/metastatic brain tumor in another invertebrate, larval Drosophila, indicating that biochem- 
ical and cellular metastatic mechanisms are similar to those in metastatic human tumors (Woodhouse et al. 1994).

Elston et al. (1992) wondered if gonadal neoplasms would be difficult to differentiate from disseminated neoplasias (hemopoietic sarcomas) which have crossed the epithelial basement membrane and invaded gonadal follicles and gonoducts without the use of ultrastructural studies. Although this may be a concern in some germinomas of less-studied species, hundreds of specimens of Mya arenaria with both types of neoplasms (in separate specimens from separate locations) have been examined, and the morphotypes and behavior of the neoplastic cells are distinct in this species.

The neoplasm in the Pawcatuck River Crassostrea virginica had the most advanced stromal development of any bivalve neoplasm of germinal origin that we examined. In particular, the truncated mass invading the branchial vein suggests deliberate formation of new gonadal follicles within the tumor. We have diagnosed this neoplasm as a gonadoblastoma, based on the appearance of immature and variably differentiated germ cells, stromal cells, and the ability to form new follicles as the tumor grows. The stroma itself also appears to be neoplastic, derived from a gonadal stem cell precursor, rather than the normal fibrovascular tissues that customarily nourish and support tumor growth (Kaiser 1989). In the human counterpart (see Scully 1970, Kissane \& Anderson 1985), gonadoblastomas arise in dysgenetic gonads, where the patient is a phenotypic female, but usually a genotypic male (having a Y chromosome), and are tumors composed of mixed germ cells (dysgerminoma and seminoma), sex cord, and stromal cells. While differing from the human disease in several respects, including the lack of dense hyaline bodies and calcifications, it appears that this neoplasm lacks the capacity to develop into normal male or female cells and represents an invertebrate example of this tumor.

\section{Comparison of Crassostrea tumors}

In light of the present findings from the Rhode Island oysters, there is good reason to believe that the RTLA 37 tumor in Crassostrea gigas, originally believed to be a fibroma, is also a gonadoblastoma. Although tubular or follicular structures were present in the periphery of the tumor, Pauley \& Sayce (1968) argued that this neoplasm in $C$. gigas could not have been of germ cell origin because the tumor cell nuclei were smaller than those of normal germ cells in adjacent gametogenic tubules, most cells were spindle-shaped, and they stained consistently for smooth muscle both by Van Gieson's technique and by Mallory's phosphotungstic acid hematoxylin procedure. Sparks (1985) interpreted this lesion as a myofibroma, because the cells tended toward a spindle shape with long bipolar cytoplasmic extensions and the special stains supported an origin from smooth muscle cells. He also interpreted this tumor as being benign based on the well-defined area it occupied, its firm texture, its abundance of fibrous connective tissue and collagen fibers, and its presumed slow growth, based on the lack of mitotic figures.

Paraffin sections of this case archived in the RTLA were freshly stained with the modified Van Gieson's procedure. In comparison to the Crassostrea virginica neoplasm, RTLA 37 exhibited only slight stromal development. The epithelial cells of the gonadal follicles, as well as the tumor cells and other epithelial cells, stained yellow, just as muscle cells are supposed to stain with this technique. We know of no biologic stains or histochemical procedures to use on formalinfixed paraffin-embedded tissues that would sufficiently distinguish by color between an epithelial and a muscle cell of origin. This question may only be answered by using immunohistochemical procedures to test for antibodies to cell-specific intermediate filaments or to cytoskeletal proteins, such as the cytokeratins for epithelial cells, and desmin or actin, respectively, for connective tissue and muscle cells (Stamp 1989).

Spindle-shaped cells also occurred in the Crassostrea virginica tumor from the Pawcatuck River, and since these cells were in gonadal follicles in the $C$. gigas specimen, they could be gametogenic in nature. Closer examination also revealed that the neoplastic cells were invading adjacent mantle tissue in some areas, with minimal compression elsewhere, and that a few mitotic figures were present. The lack of obvious mitotic figures may result from recent completion of the cell cycle, during early autolysis from handling stresses, or from delay prior to fixation (Cross et al. 1990, H. L. Stewart pers. comm.). However, because of the variety of cells found in this neoplasm, including clusters of hyperchromatic nuclei resembling sperm differentiation, this lesion may also be a gonadoblastoma.

\section{Etiologic agents of bivalve gonadal neoplasia}

Many of these gonadal neoplasms were found in animals from pollutant-compromised environments (e.g. Arctica islandica: Breton Reef dumpsite, of Newport, Rhode Island; Cardium (Cerastoderma) edule: Cork Harbour, Ireland; Mya arenaria: Searsport oil spill site, Maine; $M$. edulis (trossulus?): Anacortes diesel oil spill site, Puget Sound, Washington; Macoma calcarea: sim- 
ulated oil spill, Baffin Island, Canada). However, laboratory exposures to xenobiotics have not resulted in reproductive neoplasms (Couch et al. 1979, P. P. Yevich unpubl.), and the role of pollutants and/or viruses in the etiology of molluscan neoplasms in general awaits confirmation (Couch \& Harshbarger 1985, Mix 1986. 1988). Gardner et al. (1991a) reported that 4 out of 295 Crassostrea virginica experimentally exposed to Black Rock Harbor (BRH) dredge spoil sediment in a laboratory flow-through seawater system for 30 or $60 \mathrm{~d}$ had multiple polyps that originated in the germinal epithelium and projected into lumens of gonadal follicles. The polyps were pedunculate and some had a papillary pattern. The lesions were different from those described in this paper. Several other neoplasms were also found during these exposures. RTLA 5248 was the only $C$. virginica from a second experiment by Gardner et al. (1987) to show a germinoma after $31 \mathrm{~d}$ of exposure to BRH sediments, so the oyster may have had the condition before the experiment began, or perhaps the sediment contained substances that promoted lesion development.

The Mya arenaria germinomas were found at a site in Long Cove, Searsport, Maine, where a spill of No. 2 fuel oil and JP 5 jet fuel had occurred in 1971 (Yevich \& Barszcz 1976, 1977, Brown et al. 1977) and the lesions were initially linked to these chemical contaminants. Yevich \& Barszcz (1977), however, found no gonadal neoplasms in $M$. arenaria exposed to oil hydrocarbons in the laboratory but Gilfillan et al. (1977) did find the germinomas at a site in Maine not exposed to oil. Harshbarger et al. (1979) noted intranuclear inclusions in germinoma cells and suggested the possibility that this lesion had a viral etiology that might be facilitated by the stress of the oil spill. However, subsequent electron microscopy of tumor tissue at the RTLA by Dr S. C. Chang did not confirm the presence of a virus. Gardner et al. (1991b) reported 2 more populations of $M$. arenaria with germinomas in Maine. The only factor that these sites had in common with the earlier Searsport sites was a high level of exposure to herbicides (Tordon $101 ; 2,4-\mathrm{D} ; 2,4,5-\mathrm{T}$ ) used in blueberry agriculture, from forestry industries spraying coastal railroad rights-of-way, and from the Maine Highway Department's spraying of its rights-of-way and cleaning of its spray tanks in Searsport. These herbicides have also been linked to tumors of the reproductive tract in the military working dogs that served in Vietnam (Hayes et al. 1990). Based on this epidemiological evidence, Gardner et al. (1991b) proposed an herbicide etiology for the softshell germinomas; herbicides may also prove to be a factor in the Mercenaria germinomas (Van Beneden et al. 1993). Relevant laboratory experiments are under way to test this theory in M. arenaria.
As in other neoplasms of marine bivalve molluscs, we are only in the earliest phases of understanding the role of chemical contaminants and their metabolites as tumor initiators or promoters and the mechanisms underlying oncogene activation and cellular transformation, while the contributions of viral agents cannot yet be ruled out. Bert et al. (1993) noted that the high frequency of gonadal neoplasia in hybrid Mercenaria implicated a genetic mechanism in the etiology of the disease, which has been confirmed by Van Beneden et al. (1993). Further experimental studies and more in-depth analyses of field populations will be required.

\section{Changes in terminology}

Barry \& Yevich (1972) discussed criteria for the classification of gonadal tumors in bivalves, noting that 'It is inevitable that certain differences will exist between neoplastic changes in invertebrate forms and those acknowledged in classical mammalian oncology' (Barry \& Yevich 1972, p. 95). They proposed that information from microscopic anatomy and histogenic and oncogenic data be applied to distinguish types of gonadal tumors. Cheng (1976) urged caution in interpreting neoplastic lesions and recommended the use of molecular markers to distinguish between reaction cells and true neoplastic conditions. The rapidly growing use of immunohistochemical techniques by mammalian oncologists to identify neoplastic cells has already been adapted to hemopoietic neoplasms in bivalves (Smolowitz \& Reinisch 1986) and offers a potentially powerful enhancement to the histological identification of gonadal tumors in bivalves. Other developments in identifying chromosomal abnormalities to assist in understanding complex neoplastic diseases should also be investigated (e.g. Nichols et al. 1990).

Several authors have cautioned about the use of mammalian pathological terms in the invertebrates (Sparks 1985, Cooper 1989), but reproductive biology is such a fundamentally basic process in metazoans that these terms should be generic, rather than reserved for discussions of mammals. The terms 'dysgerminoma' and 'seminoma', however, traditionally refer to malignant neoplasms of the ovary and testes, respectively, in vertebrate animals having these organs (Dorland's Illustrated Medical Dictionary 1981, Stedman's Medical Dictionary 1982). We propose that the neoplasms of the ovarian or testicular gonadal tissue in the bivalves that arise from undifferentiated germ cells be designated as 'germinomas' only, since ovaries and testes are lacking and since the differentiation of the sex cells may change over time in some species. 


\section{CONCLUSIONS AND OTHER ISSUES}

Germinoma is the second most frequently diagnosed neoplasm of marine bivalve molluscs (Mix 1986). Review of hundreds of cases of marine bivalves archived in the RTLA revealed 3 stages in the progression of this tumor type, from focal lesions affecting individual follicles to infiltration of undifferentiated germ cells in adjacent gonadal tissue to metastasis. Epizootics of germinomas have been found in clams and oysters. A second, anecdotal, neoplastic histotype arising in the gonadal tissue of marine bivalves was of stromal origin; tumors of this histotype were morphologically varied. The third histotype discussed in this review represents a neoplasm of mixed germ cell and stromal origin, and was diagnosed as a gonadoblastoma in 3 cases from the RTLA collection

Stewart (1976) noted that years of study of hundreds of specimens are often required to sort out the morphology, behavior, and biochemistry of neoplastic diseases. While some gonadal neoplasms of marine bivalve molluscs may still be inadequate in numbers to fulfill Stewart's admonition, sample sizes of Mya arenaria and Mercenaria spp. from a number of different studies have enabled us to make good progress in analyzing their nature. More work needs to be done on possible etiologies of these diseases, especially if more examples are found at polluted sites.

Research on the roles of biotic and abiotic agents in the development of gonadal tumors in marine bivalve molluscs may be directed by other observations. For example, low-grade inflammatory responses were present in the adjacent connective tissue of most of the germinomas in the RTLA collection. Inflammatory responses have been associated with exposure to pollutants (e.g. Couch et al. 1979, Neff et al. 1987, Sunila 1987, 1988. Farley 1988) and pathogens, as well as with tumors (see Pauley 1969. Sparks 1985, see also Lauckner 1983 for review). Barry \& Yevich (1972) noted that this did not occur in Mercenaria germinomas, which was confirmed during this review. Leukocyte infiltration is a common immunogenic response to tumors in mammalian tissues (see Kaiser 1989) and fish (Schmale \& McKinney 1987).

Graves et al. (1989) reported that immunogenicity and the recruitment of human monocytes transforming into macrophages in tumors does not appear to be associated with immune recognition of neoplastic cells, but rather the level of a chemoattractant (smooth muscle cell-derived chemotactic factor) produced by a variety of tumor cells. In vertebrates, it is believed that macrophages may either stimulate tumor growth through the production of proliferative and angiogenic factors or exert an inhibitory effect through the production of other factors such as interferon, tumor necrosis factor, and transforming growth factor-B. Cooper (1989) advised caution in comparing the molluscan hemopoietic defense mechanisms with those of vertebrates. Hemocytosis, however, may be involved in the apparent remission of the disseminated hemopoietic sarcomas of Mya arenaria and Mytilus edulis (see Elston et al. 1988, Peters 1988). Possible tumorpromoting or cytotoxic proteins recently have been discovered in the serum of $M$. arenaria with hemopoietic sarcomas (Sunila \& Dungan 1992) and chemotaxis has been demonstrated in molluscan hemocytes (Sminia \& van der Knaap 1987)

Additional biochemical analyses, electron microscopy, molecular techniques, and other emerging biomedical technologies should be applied to the study of gonadal neoplasia in marine bivalve molluscs to identify the etiologic agent(s) and to elucidate the mechanism(s) of disease. Descriptions and diagnoses of the various categories of gonadal lesions presented here provide a basis or perspective for further comparative investigations on the nature, etiology, and pathogenesis of reproductive tumors in marine bivalve molluscs.

Acknowledgements. We acknowledge with appreciation all of the people listed in this paper who contributed material to the RTLA so it could be available for comparative studies. We are especially indebted to those who assisted in the preparation of this manuscript. We are also most grateful to Drs H. L. Stewart and A. G. Liebelt, Registry for Tumors in Experimental Animals, National Cancer Institute (NCI), for kindly reviewing the material with us. We thank Art Ganz, Rhode Island Department of Environmental Management, for field assistance during the collection of the Pawcatuck River oysters. D. J. Borsay and K. L. Price prepared the histoslides and performed the special stains. H. B. McCarty and M. M. Martin critically reviewed the manuscript. E.C.P. was supported by a National Research Service Award Training Fellowship (Award Number F32 CA 08327 from the NCI) during the preparation of this manuscript.

Mention of product names does not imply endorsement by the United States Environmental Protection Agency (U.S. EPA). Although the research described in this article was partially funded by the U.S. EPA, it has not been subjected to Agency review and therefore does not necessarily reflect the views of the Agency and no official endorsement should be inferred. This research was supported in part by the Registry of Tumors in Lower Animals, National Cancer Institute contracts NO1CP-61063 and NO1-CP-15641 awarded to the Smithsonian Institution.

\section{LITERATURE CITED}

Barry, M. M., Yevich, P. P. (1972). Incidence of gonadal cancer in the quahog Mercenaria mercenaria. Oncology 26: 87-96

Barry, M., Yevich, P. P. (1975). The ecological, chemical and histopathological evaluation of an oil spill site. III Histopathological studies. Mar. Pollut. Bull. 6(11): 171-173 Bert, T. M., Hesselman, D. M., Arnold, W. S., Moore, W. S. Cruz-Lopez, H., Marelli, D. C. (1993). High frequency of gonadal neoplasia in a hard clam (Mercenaria spp.) hybrid zone. Mar. Biol. 117: 97-104 
Brown, R. S., Wolke, R. E., Saila, S. B., Brown, C. W. (1977). Prevalence of neoplasia in 10 New England populations of the soft-shell clam (Mya arenaria). Ann. N.Y Acad. Sci. 298: $522-534$

Buroker, N. E., Chanley, P., Cranfield, H. J., Dinamani, P. (1983). Systematic status of two oyster populations of the genus Tiostrea from New Zealand and Chile. Mar. Biol. 77: 191-200

Cason, J. E. (1950). A rapid one-step Mallory-Heidenhain stain for connective tissue. Stain Technol. 25: 225-226

Chanley, P., Dinamani, P. (1980). Comparative descriptions of some oyster larvae from New Zealand and Chile, and a description of a new genus of oyster, Tiostrea. N.Z. J. mar Freshwat. Res. 14(2): 103-120

Cheng. T C. (1976). Identification of proliferative lesions in mollusks. Mar. Fish. Rev. 38(10): 5-6

Cooper, K. R. (1989). Regression of neoplasms in invertebrates with special emphasis on mollusca. In: Herberman R. B. (ed.) Influence of the host on tumor development cancer growth and progression, Vol. 4. Kluwer Academic Publishers, Dordrecht, p. 30-36

Cosson-Mannevy, M. A., Wong, C. S., Cretney, W. J (1984) Putative neoplastic disorders in mussels (Mytilus edulis) from southern Vancouver Island waters, British Columbia J. Invertebr. Pathol. 44: 151-160

Couch, J. A., Courtney, L. A., Winstead, J. T., Foss, S. S (1979). The American oyster (Crassostrea virginica) as an indicator of carcinogens in the aquatic environment. In Animals as monitors of environmental pollutants (Proceedings of the Symposium on Pathobiology of Environmental Pollutants: Animal Models and Wildlife as Monitors, University of Connecticut, 1977). National Academy of Sciences, Washington, DC, p. 65-84

Couch, J. A., Harshbarger, J C. (1985). Effects of carcinogenic agents on aquatic animals: an environmental and experimental overview. Environ. Carcinogenesis Rev. 3(1): $63-105$

Cross, S. S., Start, R. D., Smith, J. H. F. (1990). Does delay in fixation affect the number of mitotic figures in processed tissue? J. clin. Pathol. 43: 597-599

de Jong-Brink, J., Boer, H. H., Joosse, J. (1983). Mollusca. In Adiyodi, K. G., Adiyodi, R. G. (eds.) Reproductive biology of invertebrates. Vol. I: Oogenesis, oviposition and oosorption. John Wiley \& Sons, Chichester, p. 297-355

Dodds, H. M., Clark, G. (1985). An improved Van Gieson. Stain Technol. 60: 55

Dorland's Illustrated Medical Dictionary (1981). 26th edn W. B. Saunders Co., Philadelphia

Elston, R. A., Kent, M. L., Drum, A. S. (1988). Transmission of hemic neoplasia in the bay mussel, Mytilus edulis, using whole cells and cell homogenate. Dev. comp. Immunol. 12: $719-727$

Elston, R. A., Moore, J. D., Brooks, K. (1992). Disseminated neoplasia of bivalve molluscs. Rev. Aquat. Sci. 6(5,6): 405-466.

Eversole, A. G. Heffernan, P. B. (1993). Gonadal neoplasia in Mercenaria mercenaria, M. campechiensis and their hybrids. Abstracts, 1993 Annual Meeting, 31 May-3 June, National Shellfisheries Association, Portland, Oregon. J. Shellfish Res. 12(1): 50

Farley, C. A. (1976). Proliferative disorders in bivalve mollusks. Mar. Fish. Rev. 38(10): 30-33

Farley, C. A. (1978). Viruses and viruslike lesions in marine mollusks. Mar. Fish. Rev. 40(10): 18-20

Farley, C. A. (1988). Histochemistry as a tool for examining possible pathologic cause-and-effect relationships between heavy metal and inflammatory lesions in oysters,
Crassostrea virginica. Mar. environ. Res. 24: 271-275

Galstoff, P. S. (1964). The American oyster Crassostrea virginica Gmelin. Fish. Bull. U.S. 64: 1-480

Gardner, G. R., Yevich, P. P.. Malcolm, A. R., Pruell, R. J. (1987). Carcinogenic effects of Black Rock Harbor sediment on American oysters and winter flounder. National Cancer Institute and U.S. Environmental Protection Agency Collaborative Program on Environmental Cancer, project report to the National Cancer Institute. U.S Environmental Protection Agency, Environmental Research Laboratory, Narragansett, Rl (ERLN). ERLN Contribution No. 901

Gardner, G. R., Yevich, P. P., Harshbarger, J. C., Malcolm, A. R. (1991a). Carcinogenicity of Black Rock Harbor, Bridgeport, CT sediment to the American oyster (Crassostrea virginica) and trophic transfer of Black Rock Harbor carcinogens from the blue mussel (Mytilus edulis) to the winter flounder (Pseudopleuronectes americanus) Environ. Health Perspect. 90: 53-66

Gardner, G. R., Yevich, P. P., Hurst, J., Thayer, P., Benyi, S. Harshbarger, J. C., Pruell, R. J. (1991b). Germinomas and teratoid siphon anomalies in softshell clams, Mya arenaria, environmentally exposed to herbicides. Environ. Health Perspect. 90: 43-51

Gilfillin, E. S., Hanson, S. A., Page, D. S., Mayo, D., Cooley, J., Chalfant, J., Archambeault, T., West, A., Harshbarger, J. C. (1977). Final Report to the Department of Environmental Protection. Contract No. 906439, State of Maine Department of Environmental Protection

Graves, D. T., Jiang, Y. L., Williamson, M. J., Valente, A. J. (1989). Identification of monocyte chemotactic activity produced by malignant cells. Science 245: 1490-1493

Harshbarger, J. C., Otto, S. V., Chang, S. C. (1979). Proliferative disorders in Crassostrea virginica and Mya arenaria from the Chesapeake Bay and intranuclear viruslike inclusions in Mya arenaria with germinomas from a Maine oil spill site. Haliotis 8: 243-248

Hayes, H. M., Tarone, R. E., Casey, H. W., Huxsoll, D. L. (1990). Excess of seminomas observed in Vietnam Service U.S. military working dogs. J. Nat. Can. Inst. 83: $1042-1046$.

Hesselman, D. M., Blake, N. J., Peters, E. C. (1988). Gonadal neoplasms in hard shell clams Mercenaria spp., from the Indian River, Florida: occurrence, prevalence, and histopathology. J. Invertebr. Pathol. 52: 436-446

Kaiser, H. E. (1989). Stroma, generally a non-neoplastic structure of the tumor. In: Liotta, L. A. (ed.) Influence of tumor on host development, cancer growth and progression, Vol. 3. Kluwer Academic Publishers, Dordrecht, p. 1-8

Kissane, J. M., Anderson, W. A. D. (1985). Anderson's pathology, 8th edn. The C. V. Mosby Co., St. Louis

Kraemer, L. R. (1986). Biological basis of behavior in Corbicula fluminea, II. Functional morphology of reproduction and development and review of evidence for self-fertilization. Am. malacol. Bull. Spec. Ed. 2: 193-201

Lauckner, G. (1983). Neoplasia. In: Kinne, O. (ed.) Diseases of marine animals. II. (Mollusca) Bivalvia to Scaphopoda. Biologische Anstalt Helgoland, Hamburg, p. 863-879

Luna, L. G. (ed.) (1968). Manual of histologic techniques of the Armed Forces Institute of Pathology, 3rd edn. McGraw-Hill, New York

Maxwell, W. L. (1983). Mollusca. In: Adiyodi, K. G., Adiyodi, R. D. (eds.) Reproductive biology of invertebrates. Vol. II: Spermatogenesis and sperm function. John Wiley \& Sons, Chichester, p. 275-319

McDonald, J. H., Koehn, R. K. (1988). The mussels Mytilus galloprovincialis and $M$. trossulus on the Pacific coast of 
North America. Mar Biol. 99; 111-118

Mix, M. C. (1986). Cancerous diseases in aquatic animals and their association with environmental pollutants: a critical literature review. Mar. environ. Res. 20: 1-141

Mix, M.C. (1988). Shellfish diseases in relation to toxic chemicals. Aquat. Toxicol. 11. 29-42

Neff, J M., Hillman, R. E., Carr, R. S., Buhl, R. L., Lahey, J. I. (1987). Histopathologic and biochemical responses in Arctic marine bivalve molluscs exposed to experimentally spilled oil. Arctic 40 (Suppl. 1): 220-229

Nichols, C. R., Roth, B. J., Heerema, N., Griep, J., Tricot, G. (1990). Hematologic neoplasia associated with primary mediastinal germ-cell tumors. New Engl. J. Med. 322: $1425-1429$

Nieuwkoop, P. D., Satasurya, L. A. (1981). Primordial germ cells in the invertebrates: from epigenesis to preformation. Cambridge University Press, Cambridge

Pauley, G. B. (1969). A critical review of neoplasia and tumorlike lesions in mollusks. Nat. Cancer Inst. Monogr 31 $509-539$

Pauley, G. B., Sayce, C. S. (1968). An internal fibrous tumor in a Pacific oyster Crassostrea gigas. J Invertebr. Pathol. 10: $1-8$

Peters, E.C. (1988). Recent investigations on the disseminated sarcomas of marine bivalve molluscs. Am. Fish. Soc. Spec. Publ. 18: 74-92.

Sanders, B. J. (1973). Animal histology procedures of the Pathological Technology Section of the National Cancer Institute. \#1742-0043, U.S. Government Printing Office, Washington, DC

Schmale, M. C., McKinney, E. C. (1987). Immune responses in the bicolor damselfish. Pomacentrus partitus, and their potential role in the development of neurogenic tumours. J. Fish. Biol. 31 (Suppl. A): 161-166

Scully, R. E. (1970). Gonadoblastoma: a review of 74 cases. Cancer 25: 1340-1356

Scully, R. E. (1979). Tumors of the ovary and maldeveloped gonads. Atlas of Tumor Pathology, Fascicle 16. Armed Forces Institute of Pathology, Washington, DC

Sminia, T., van der Knaap, W. P. W. (1987). Cells and molecules in molluscan immunology. Dev. comp. Immunol. 11: $17-28$

Smolowitz, R. M., Reinisch, C. L. (1986). Indirect peroxidase staining using monoclonal antibodies specific for Mya arenaria neoplastic cells. J. Invertebr. Pathol. 48: 139-145

Sparks, A. K. (1985). Synopsis of invertebrate pathology, exclusive of insects. Elsevier Science Publishing, Amsterdam

Stamp, G. W. H. (1989). Evaluation of immunohistochemistry

Responsible Subject Editor: A. K. Sparks, Seattle,

Washington, USA in tumor diagnosis. J. Histotech. 12: 323-332

Stedman's Medical Dictionary (1982). 24th edn. Williams \& Wilkins, Baltimore

Stewart, H. L. (1976). Some observations on comparative vertebrate and invertebrate pathology: a summary discussion of the workshop. Mar. Fish. Rev. 38(1.0): 46-48

Sunila, 1. (1987). Histopathological effects of environmental pollutants on the common mussel, Mytilus edulis L. (Baltic Sea), and their application in marine monitoring. Academic dissertation, University of Helsinki

Sunila, I. (1988). Pollution-related histopathological changes in the mussel Mytilus edulis L. in the Baltic Sea. Mar. environ. Res. 24: $277-280$

Sunila, I., Dungan, C. F. (1992). Different proteins in the hemolymph sera from sarcomatous and healthy soft shell clams, Mya arenaria L. Comp. Biochem. Physiol. 102B 621-625

Twomey, E., Mulcahy, M. F. (1988). Transmission of a sarcoma in the cockle Cerastoderma edule (Bivalvia: Mollusca) using cell transplants. Dev. comp. Immunol. 12: 195-200

Van Beneden, R. J., Gardner, G. R., Blake, N. J., Blair, D. G. (1.993). Implications for the presence of transforming genes in gonadal tumors in two bivalve mollusk species. J. Cancer Res. 53: 2976-2979

Woodhouse, E., Hersperger, E., Stetler-Stevenson, W. G. Liotta, L., Shearn, A. (1994). Increased type IV collagenase in $\mathrm{lgl}$-induced invasive tumors of Drosophila. Cell Growth Differ. 5: 151-159.

Yevich, P. P., Barry, M. M. (1969). Ovarian tumors in the quahog Mercenaria mercenaria. J. Invertebr. Pathol. 14 $266-267$

Yevich, P. P., Barszcz, C. A. (1976). Gonadal and hematopoietic neoplasms in Mya arenaria. Mar. Fish. Rev. 38(10) $42-43$

Yevich, P. P., Barszcz, C. A. (1977). Neoplasia in soft-shell clams (Mya arenaria) collected from oil-impacted areas. Ann. N. Y Acad. Sci. 298: 409-426

Yevich, P. P., Barszcz, C., Pesch, G., Nelson, W. (1987). Effects of Black Rock Harbor dredged material on the histopathology of the blue mussel Mytilus edulis and polychaete worm Nephtys incisa after laboratory and field exposures Technical Report D-87-8, prepared by the U.S. Environmental Protection Agency, Narragansett, RI, for the U.S Army Engineer Waterways Experiment Station, Vicksburg, MS

Zaroogian, G., Yevich, P. (1993). Cytology and brochemistry of brown cells in Crassostrea virginica collected at a clean and at a contaminated site. Environ. Pollut. 79: 191-197

Manuscript first received: March 4, 1991

Revised version accepted: April 27, 1994 